\title{
The USEFULnesS OF SOUth AfRican AnNUAL RePORTS AS AT DECEMBER 2010
}

\author{
Lucien Olandzobo Dimi* \\ University of the Witwatersrand \\ Nirupa Padia" \\ Warren Maroun+ \\ University of the Witwatersrand \\ nirupa.padia@wits.ac.za. \\ University of the Witwatersrand \\ Warren.maroun@wits.ac.za
}

Received: June 2012

Accepted: November 2013

\begin{abstract}
This article provides an account of the extent to which South African annual reports, as at the end of 2010, comply with the fundamental and enhancing qualitative characteristics of decision-useful information. Using the frameworks provided by the International Accounting Standards Board and Integrated Reporting Committee of South Africa, the research provides a normative assessment of the quality of South African annual reports at the transition to integrated reporting, which can be used by future researchers wishing to study the effect of an integrated reporting model on corporate reporting. Based on the views of a selection of corporate reporting experts, the article finds that certain aspects of South African companies' corporate reports are regarded as providing useful information to users. There are also areas in need of improvement, most notably the disclosure of non-financial information and the integration of this information with the financial performance and strategic vision of the organisation.
\end{abstract}

Keywords

Annual reports, usefulness, corporate reporting, disclosure, financial information; integrated reporting; nonfinancial information

*Mr L Dimi is a master's student at the School of Accountancy, University of the Witwatersrand, South Africa.

\#Prof N Padia is the Head of the School of Accountancy, University of the Witwatersrand, South Africa.

+Prof W Maroun is a professor in the School of Accountancy, University of the Witwatersrand, South Africa. 


\section{INTRODUCTION}

In terms of agency theory, financial reporting is part of the system of checks and balances designed to reduce information asymmetries between managers and shareholders (Watts \& Zimmerman, 1983). Producing high-quality financial statements ensures that the information needs of current and potential investors are serviced (International Accounting Standards Board [IASB], 2010), ensuring the efficient allocation of capital (Barth, 2008).

With the publication of South Africa's first codes of corporate governance, and the advent of 'triple-bottom-line reporting', the focus on communicating only financial information to shareholders has been superseded by a stakeholder-orientated model of corporate reporting that also places emphasis on non-financial information (Institute of Directors in Southern Africa [IOD], 1994; IOD, 2002; Solomon 2010). The 2007/2008 financial crisis has accentuated this (Integrated Reporting Committee of South Africa [IRC], 2011). In the interest of communicating the ability of organisations to create and sustain value in the short, medium and long term, the integrated reporting initiative has called for meaningful stakeholder engagement that links the economic performance of organisations with their non-financial metrics, risk management and business strategy (IRC, 2011; I0D, 2009).

The requirement for listed companies to prepare an integrated report, or provide reasons for not doing so, is a fairly recent occurrence, introduced by the Johannesburg Securities Exchange (JSE) for years ending on or after 1 March 2010 (Deloitte, 2012; Morales \& Van Tichelen, 2010). An empirical analysis of the long-term effects of integrated reporting on South African corporate governance is, therefore, not possible. What is needed, however, is an initial assessment of the state of corporate reporting at the time of transition to integrated reporting that can be used as a 'base case' for future research. To this end, this article explores the usefulness of annual reports for years ending on or before 31 December 2010. The qualitative characteristics in the Conceptual Framework for Financial Reporting (CF), issued by the IASB (IASB, 2010), and the reporting principles highlighted by the IRC's (2011) Framework for Integrated Reporting and the Integrated Report serve to 'describe' the characteristics of South African annual reports.

A structured questionnaire and factor analysis are used to aggregate the views of a selection of corporate governance experts on the perceived usefulness of corporate reports. The research is inspired by an interpretive epistemology; does not purport to offer a 'scientific' conclusion; and is essentially normative. Nevertheless, the exploratory focus allows the article to make a number of important contributions. It offers evidence to support the assertions of King III (2009) and the IRC (2011) that a paradigm shift in favour of more integrated and holistic corporate reporting is needed if annual reporting by listed companies is to remain relevant and credible. In addition, the research provides a 'base' that subsequent researchers, reflecting on 2010, may use to evaluate the progress made by the preparers of annual/integrated reports (see Hayek, 1960). Finally, the article should also be of interest to practitioners seeking to improve their integrated reports.

The remainder of this article is organised as follows. Section 2 provides a theoretical overview and develops the research questions included in the structured questionnaire and factor analysis. Section 3 explains the method. Section 4 presents and discusses the findings. Section 5 concludes and identifies areas for future research. 


\section{PRIOR LITERATURE: DEVELOPMENT OF THE RESEARCH INSTRUMENT}

Several researchers have attempted to measure the quality of annual reports using surrogates such as earnings management indicators (see Barth, Landsman \& Lang, 2008; Graham, Harvey \& Rajgopal 2005; Healy \& Wahlen, 1999; Van Beest, Braam \& Boelens, 2009) or the relationship between accounting balances and stock prices (see Nichols \& Wahlen, 2004; Barth, Beaver \& Landsman 2001; Bartov, Goldberg \& Kim, 2005). Studies addressing the usefulness of annual reports with reference to financial and non-financial metrics are, however, comparatively rare (Jonas \& Blanchet 2000; McDaniel, Martin \& Maines, 2002; Van Beest et al., 2009). To date, there is scant research employing qualitative characteristics - as defined by either the CF (IASB, 2010) or the IRC (2011) - to assess the perceived usefulness of annual reports at a point in time.

According to the CF, the objective of financial statements is to provide financial information that is useful to both current and potential capital providers in making economic decisions (IASB, 2010). For financial information to be useful it needs to be both a relevant and faithful representation of underlying economic circumstances and events. This is complemented by information that is comparable, verifiable, understandable and presented timeously (IASB, 2010). Similar characteristics apply to non-financial information. The IRC (2011) recommends that, when preparing an integrated report, preparers be equally mindful of the need to communicate relevant information in a fashion that achieves fair presentation by ensuring completeness, neutrality and accuracy. Therefore, comparability, verifiability, timeliness of reporting and clarity remain important quality considerations (IRC, 2011; Solomon and Solomon, 2006). A similar approach is followed by the International Integrated Reporting Committee (IIRC) (2011).

For the purpose of this research the fundamental characteristics of relevance and faithful presentation, as well as the enhancing characteristics of comparability, verifiability, timeliness and understandability (IASB, 2010; IRC, 2011), are used as a basis for describing whether or not financial and non-financial information contained in South African annual reports is perceived as useful by a group of informed users.

\subsection{Fundamental qualitative characteristics of decision-useful information}

Per the CF (IASB, 2010), IRC (2011) and IIRC (2011) financial and non-financial information is useful only if it is relevant. This means that information needs to have both predictive and confirmatory potential, allowing it both to influence the decision-making process (IASB, 2010) and assist stakeholders in appropriately evaluating the company's performance and its capacity to create and sustain value over the short, medium and long term (IRC, 2011; Jonas \& Blanchet, 2000). For example, financial reports providing forward-looking information that can assist users to form expectations about a company's future performance or confirm initial earnings or cash flow projections would be relevant (IASB, 2010; IASB, 2010a; IRC, 2011; Bartov \& Mohanram 2004; Van Beest et al., 2009). This is especially the case when forward-looking financial information is complemented by detailed disclosure of a company's objectives, strategies, business opportunities, risks and risk management policies (IRC, 2011; Jonas \& Blanchet 2000; Solomon \& Maroun, 2012). Accordingly, the following two questions are included in the data collection instrument (Section 3$)$ : 
R1: To what extent does the presence of forward-looking information help users form expectations and predictions concerning the future of the company?

R2: To what extent does the presence of non-financial information - in terms of the overview of the organisation, its objectives, business opportunities and risks - complement financial information?

Social, health and environmental disclosures are also important (Solomon, 2010; 10D, 2009; Solomon \& Solomon, 2006; Cohen, Krishnamoorthy \& Wright, 2002). For South Africa in particular, HIV/Aids, occupational health and safety and black economic empowerment are very relevant for stakeholders (Reed, 2003; Vaughn \& Ryan, 2006; Solomon \& Maroun, 2012). In the spirit of sustainability and responsible business management, each of these governance issues should inform an organisation's risk assessment, strategic objectives and annual reporting (IRC, 2011; Botten, 2009; Rossouw, 2005).

R3: To what extent is corporate governance-related disclosure found in annual reports - in terms of social, health, environmental and compliance issues - useful for different stakeholders?

R4: To what extent do annual reports communicate strategic objectives informed by risks, opportunities, macro-economic developments, social issues and sustainability?

R5: To what extent does the annual report allow stakeholders to evaluate the organisation's long- and short-term performance, as well as its sustainability?

For the above to be relevant, it is imperative that they faithfully represent the underlying economic or social reality (IASB, 2010; IRC, 2011). This implies the absence of material bias and error (IOD, 2009; Solomon, 2010). Although complete accuracy is unlikely, users would expect significant assumptions and estimates to be appropriate and free from material misstatements (IASB, 2010; IAASB, 2010; Jonas \& Blanchet, 2000). In the interest of transparency, significant accounting policy choices should also be disclosed and explained (Maines \& Wahlen, 2006; IASB, 2010b).

Fl: To what extent are the significant assumptions and estimates in the annual reports explained?

F2: To what extent do annual reports explain the accounting policy choices pertaining to the financial statements?

Companies should avoid using sections, formats and presentations in their annual reports that could obscure the faithful presentation of financial and non-financial reporting. In particular, positive and negative transactions, events and conditions ought to be reported (IASB, 2010a; IOD, 2009; IRC, 2011). 'Slanted, weighted, emphasised, de-emphasised or otherwise manipulated' disclosures are inconsistent with the principle of fair presentation (IASB, 2010: QC14; Van Beest et al., 2009; IRC, 2011). In other words, financial and non-financial disclosures ought to present the true state of affairs of the organisation (IOD, 2009; IASB, 2010a; IRC, 2011).

F3: To what extent do companies highlight negative as well as positive transactions, events and conditions in their annual reports?

F4: To what extent are the disclosed strategies, values, risks, risk-management policies, social/health/environmental issues, and financial performance of the firm a faithful representation of the actual state of affairs? 
Finally, the need for high-quality decision-useful information also makes the case for integrated reporting (IOD, 2009). Reports emphasising only the financial performance of a company are unlikely to provide a faithful representation of the ability of the organisation to create and sustain value in the short, medium and long term (Solomon \& Maroun, 2012; Solomon \& Solomon, 2006). Stakeholders require progressive reporting that clearly links sustainability issues with an organisation's core strategies and its economic performance (IRC, 2011).

F5: To what extent is non-financial information integrated with the financial information contained in annual reports?

\subsection{Enhancing characteristics of decision-useful information}

According to the CF (IASB, 2010:(2)19), 'comparability, verifiability, timeliness and understandability are qualitative characteristics that enhance the usefulness of information that is relevant and faithfully represented'. 'Comparability' implies that similar transactions, events and circumstances are accounted for and reported in a similar fashion (IASB, 2010). Restatements or retrospective adjustments (IASB, 2010b) should, thus, be limited to correction of prior period errors or to circumstances where changes would provide more relevant information to users respectively (see also Costello \& WittenBerg-Moerman, 2011; Graham, Li \& Qiu, 2008; Akhigbe, Kudla \& Madura, 2005; Baker \& Hayes, 2004). Where changes in accounting policies or correction or errors occur, the nature and effect of the changes should be fully disclosed (IASB, 2010b; IASB, 2010c; IRC, 2011). The same would apply, mutatis mutandis, to non-financial information (IRC, 2011; IIRC, 2011).

$\mathrm{Cl}$ : How frequently do companies retrospectively adjust or restate previous accounting periods' figures for implementation of a change in accounting policy or a material prior period error?

C2: To what extent do the notes on changes in accounting policies or revisions explain the implications of the respective changes?

C3: To what extent is the financial, social, economic and environmental performance of the organisation comparable from period to period?

C4: To what extent is the information in the annual reports comparable to information provided by other organisations?

Comparability counts for little if the information is not communicated clearly and timeously (IASB, 2010). At the simplest level, this amounts to ensuring that financial statements are prepared and presented in a concise, logical and structured form (Jonas \& Blanchet, 2000; IRC, 2011). Notes to the financial statements have an important role to play in this regard, elaborating on and explaining disclosures in the financial statements (Van Beest et al., 2009; IASB, 2010c).

U1: To what extent are annual reports presented in a well-organised manner (e.g. table of contents, heading and order of components)?

U2: To what extent are supporting notes to the financial statements useful for understanding the financial performance, position and cash flow of organisations?

U3: Does supplementary information (such as glossary of terms, group structures and crossreferenced electronic media) add to the clarity of the annual report? 
T1: To what extent do you feel that the time lag between the end of the reporting period and the issue of the annual financial report to stakeholders is appropriate?

\section{METHOD}

A structured questionnaire consisting of 18 questions, completed by 40 corporate governance experts, was used to explore the perceived usefulness of South African annual reports with 2010 year-ends. Experts were sourced from the country's leading universities, preparers from listed South African companies, the Big 4 Audit firms and two professional investment firms. As discussed in Section 2, the questions were derived from the prior literature, in particular the provisions of the CF (IASB, 2010) and the IRC (2011), in order to reduce the risk of researcher bias in the design of the questionnaire (Creswell, 2009; Van Beest et al., 2009).

Purposeful selection of a relatively small group of experts can lead to result bias. The approach, however, ensures that only subject experts were engaged in the study, adding to the quality of the findings (see Creswell, 2009; Rowley, 2012; Cohen et al., 2002). It should also be stressed that, given the focus on the perceptions of stakeholders, the research is inspired by an interpretive epistemology. The authors make no effort to 'quantify' the usefulness of annual reports or test hypotheses. Instead, the research provides an initial exploratory base for examining the state of South African corporate reporting as at 2010 with the aim of offering recommendations to preparers. This normative approach should not, in itself, be regarded as a threat to validity and reliability (see Creswell, 2009).

All questionnaires were completed during 2011 in Johannesburg and Cape Town. To ensure validity of responses, the questionnaire was piloted prior to the main study (see Creswell, 2009; Leedy \& Ormrod, 2001) and was designed to be easy and quick to complete in order to maximise response rates and accuracy. Respondents were guaranteed that they would remain anonymous and informed that the research was being carried out for academic purposes only (adapted from 0'Dwyer, Owen \& Unerman, 2011; Creswell, 2009).

Similar to a study by Van Beest et al. (2009), a five-point Likert scale was used, ranging, in general, from a low (1) to high (5) perceived level of usefulness (see also Abadir, 2005; Groth \& Bergner, 2006; Azam, Warraich \& Awan , 2011). Initial descriptive statistics (mode, median and mean responses) were generated, using a statistical programme (SPSS). Thereafter, the data was summarised and aggregated into different 'themes' or factors.

Factor analysis was employed for this purpose due to its widespread use in studying interrelationships (Ford MacCallum \& Tait, 1986). The method is also well suited to smaller sample sizes where the intention is to classify and describe data, rather than extrapolate findings in a more positivist sense (see Ford et al., 1986; Groth \& Bergner, 2006; Bonaci, Mustata \& Mutiu, 2011). To balance the exploratory potential of the study with ease of interpretation, only items with a loading greater than .40 were used to define each factor or 'theme' (Hatcher, 1994; Ford et al., 1986; Comrey, 1978; Rummel, 1978; Malhotra, 1996). The result was an initial correlation matrix consisting of 18 variables (each research question as per section 2) regrouped into six factors. A Varimax Method was then used to rotate the initial matrix (see Malhotra, 1996; Ford et al., 1986). This minimises the number of variables (individual research questions) with high loadings on a factor, thus ensuring enhanced interpretability (see Malhotra, 1996; Ford et al., 1986; Rummel, 1970). Principal axis factoring was used to generate the final correlation table after 18 iterations. As recommended by Malhotra (1996) and Ford et 
al. (1986), only factors with eigenvalues greater than 1.0 were retained, allowing for $60 \%$ retention of the data's exploratory potential (retained variances) as per TABLE 1 and FIGURE 1 in the Appendix.

TABLE 1: Total variance explained

\begin{tabular}{|c|c|c|c|c|c|c|c|c|c|}
\hline \multirow[b]{2}{*}{ Factor } & \multicolumn{3}{|c|}{ Initial eigenvalues } & \multicolumn{3}{|c|}{$\begin{array}{l}\text { Extraction sums of squared } \\
\text { loadings }\end{array}$} & \multicolumn{3}{|c|}{$\begin{array}{c}\text { Rotation sums of squared } \\
\text { loadings }\end{array}$} \\
\hline & Total & $\begin{array}{c}\% \text { of } \\
\text { Variance }\end{array}$ & $\begin{array}{c}\text { Cumulative } \\
\%\end{array}$ & Total & $\begin{array}{c}\% \text { of } \\
\text { Variance }\end{array}$ & $\begin{array}{l}\text { Cumu- } \\
\text { lative \% }\end{array}$ & Total & $\begin{array}{c}\% \text { of } \\
\text { Variance }\end{array}$ & $\begin{array}{c}\text { Cumu- } \\
\text { lative } \\
\%\end{array}$ \\
\hline 1 & 3.237 & 19.043 & 19.043 & 2.832 & 16.660 & 16.660 & 2.420 & 14.237 & 14.237 \\
\hline 2 & 2.531 & 14.889 & 33.932 & 2.214 & 13.021 & 29.681 & 1.920 & 11.297 & 25.534 \\
\hline 3 & 2.221 & 13.066 & 46.997 & 1.920 & 11.293 & 40.974 & 1.594 & 9.378 & 34.913 \\
\hline 4 & 1.709 & 10.056 & 57.053 & 1.260 & 7.414 & 48.388 & 1.477 & 8.690 & 43.603 \\
\hline 5 & 1.630 & 9.590 & 66.643 & 1.168 & 6.873 & 55.261 & 1.395 & 8.207 & 51.810 \\
\hline 6 & 1.102 & 6.483 & 73.126 & .777 & 4.568 & 59.829 & 1.363 & 8.018 & 59.829 \\
\hline
\end{tabular}

\section{Source: Authors' calculations}

Inspired by an interpretative approach, the six factors were derived by the researcher from the prior literature (Hatcher, 1994; Ford et al., 1986, Comrey, 1978; Rummel, 1978). Although the involvement by the researcher detracts from the validity of the study in a positivist sense, the composition of the factors themselves is determined more objectively and the experts' responses are not altered (Ford et al., 1986; Tracy, 1983). To further ensure reliability, the Bartlett's test of sphericity was used to test the null hypothesis that variables are uncorrelated, and the Kaiser-Mayer-Olkin (KMO) was used to measure sampling adequacy (Ilias \& Razak, 2011; Bonaci et al., 2011; Callaghan, 2012). The results are summarised in TABLE 2.

TABLE 2: KMO and Bartlett's tests

\begin{tabular}{lll}
\hline Kaiser-Meyer-Olkin measure of sampling adequacy. & .470 \\
\hline Bartlett's test of sphericity & Approx. chi-square & 280.222 \\
& $\mathrm{df}$ & 136 \\
& Sig. & .000 \\
\hline
\end{tabular}

Source: Authors' calculations

The KMO value is larger than the minimum value required $(.470>.3)$ and the Chi-Squared statistic (Bartlett's test of sphericity) was significant at 280.222 for 136 degrees of freedom. Hence, the null hypothesis was rejected and factor analysis was appropriate for analysing the data. This was confirmed by the reasonably high levels of correlation among the data as indicated by the commonality values summarised in the Appendix. In addition, because of the relatively small sample size, a Cronbach's alpha test was carried out (Sijtsma, 2009; Nunnally, 1962). The test revealed no material issues, although one research question (R4) was excluded from the factor analysis to strengthen the inter-variable correlations, leaving a correlation 
matrix based on 17 variables (see section 4). TABLE 1 has been adjusted to reflect this. (As a final validity check, the choice and use of the factor analysis was reviewed by an independent statistician.)

Despite the reliability and validity safeguards, however, this research is not without its limitations. Firstly, the research examines the perceptions of a relatively small number of experts. On the one hand, this is an inherent restriction, given the limited number of individuals knowledgeable about IFRS, corporate governance and integrated reporting in South Africa. A relatively small, purposefully selected group of experts is also used to ensure that only informed responses are considered (see Cohen et al., 2002; Creswell, 2009; Maroun, Turner \& Sartorius, 2011 ), although this means that responses are not representative of the entire population of stakeholders (Azam et al., 2011; Hussey \& Hussey, 2003).

Secondly, the factor analysis only summarises the perceptions of respondents, aggregating these under six themes or factors. The method does not provide a quantification of reporting quality or usefulness. Rather than seek to devise an objective scale for measuring these traits, the article is influenced by a more interpretive approach, where the researcher is involved in the development of the research questions and the analysis of the data, based on interpretation of the underlying literature. In other words, although a quantitative method is used to evaluate annual reports, the purpose is not to 'quantify' measures in a positivist sense but rather to summarise the views of a group of experts.

\section{RESULTS AND DISCUSSION}

The final factor analysis table (TABLE 3 ) is presented below. Each of the 'variables' were derived in Section 2 and they are grouped under six factors according to their mutual correlations.

TABLE 3: Factor analysis table

\begin{tabular}{l}
\multicolumn{1}{c}{ Variables } \\
$\begin{array}{l}\text { Tl: To what extent do you feel that the time lag } \\
\text { between the end of the reporting period and the }\end{array}$ \\
issue of the annual financial report to \\
stakeholders is appropriate? \\
R3: To what extent is the corporate governance- \\
related disclosure found in annual reports - in \\
terms of social, health, environmental and \\
compliance issues - useful for different \\
stakeholders? \\
C4: To what extent is the information in the \\
annual reports comparable to information \\
provided by other organisations? \\
F2: To what extent do annual reports explain \\
accounting policy choices pertaining to the \\
financial statements?
\end{tabular}




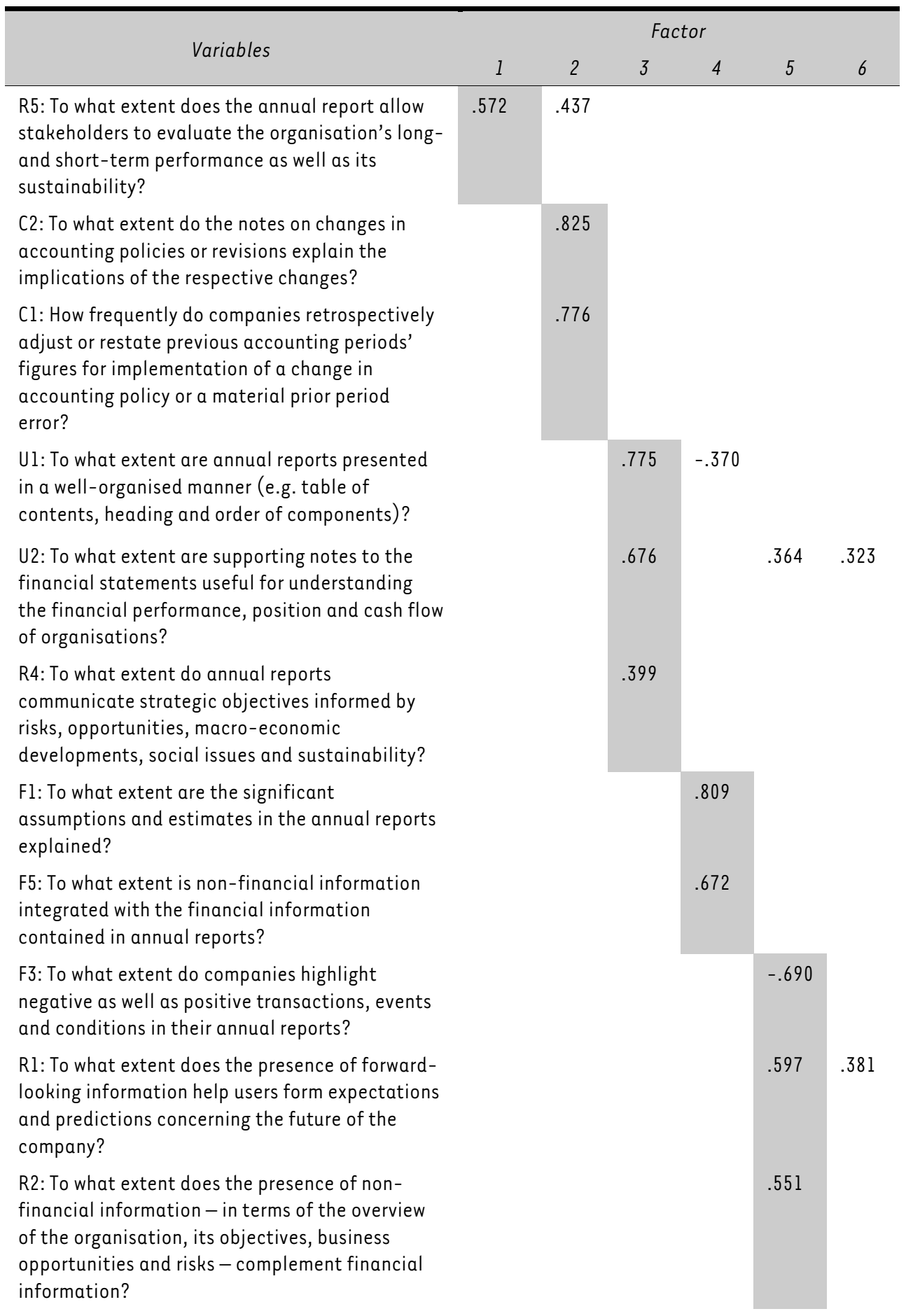




\begin{tabular}{|c|c|c|c|c|c|c|}
\hline \multirow{2}{*}{ Variables } & \multicolumn{6}{|c|}{ Factor } \\
\hline & 1 & 2 & 3 & 4 & 5 & 6 \\
\hline $\begin{array}{l}\text { F4: To what extent are the disclosed strategies, } \\
\text { values, risks, risk-management policies, } \\
\text { social/health/environmental issues, and } \\
\text { financial performance of the firm a faithful } \\
\text { representation of the actual state of affairs? }\end{array}$ & & & & & & .579 \\
\hline $\begin{array}{l}\text { U3: Does supplementary information (such as } \\
\text { glossary of terms, group structures and cross- } \\
\text { referenced electronic media) add to the clarity of } \\
\text { the annual report? }\end{array}$ & .456 & & & & & .566 \\
\hline $\begin{array}{l}\text { C3: To what extent is the financial, social, } \\
\text { economic and environmental performance of the } \\
\text { organisation comparable from period to period? }\end{array}$ & & & & & & -.435 \\
\hline
\end{tabular}

\section{Source: Authors' calculations}

The results of the Cronbach alpha reliability test (Section 3) revealed that excluding R4 (in Factor 3 ) increased the internal consistency of the factors (from .54 to .65.), confirming the suitability of final factor analysis. (Each factor had a statistic greater than the 0.50 recommended Nunnally (1962)).

\section{TABLE 4: Factor table}

\begin{tabular}{|c|c|c|c|c|c|c|c|}
\hline Factors & $N$ & $\begin{array}{l}\text { Variables } \\
\text { correlated } \\
\text { to factor }\end{array}$ & $\begin{array}{l}\text { Cronbach's } \\
\text { alpha }\end{array}$ & $\stackrel{\Sigma}{\Sigma}$ & 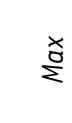 & $\begin{array}{l}\tilde{\delta} \\
\sum\end{array}$ & $\begin{array}{l}\overrightarrow{0} \\
\text { Dे } \\
\dot{ \pm}\end{array}$ \\
\hline $\begin{array}{l}\text { 1: Detail and timeliness of } \\
\text { the annual reports }\end{array}$ & 40 & $\begin{array}{l}\mathrm{T} 1, \mathrm{R} 3, \mathrm{C} 4 \\
\mathrm{~F} 2, \mathrm{R} 5\end{array}$ & .73 & 2.40 & 4.00 & 3.0950 & .45739 \\
\hline $\begin{array}{l}\text { 2: Change in accounting } \\
\text { policies }\end{array}$ & 40 & $\mathrm{Cl}, \mathrm{C} 2$ & .73 & 2.00 & 5.00 & 4.2750 & .53048 \\
\hline $\begin{array}{l}\text { 3: Understandability of the } \\
\text { annual reports }\end{array}$ & 40 & U2, U1 & .65 & 3.00 & 5.00 & 3.9750 & .40746 \\
\hline $\begin{array}{l}\text { 4: Integration of financial } \\
\text { and non-financial } \\
\text { information in the annual } \\
\text { reports and clarity of } \\
\text { estimates and assumptions }\end{array}$ & 40 & $\mathrm{Fl}, \mathrm{F} 5$ & .645 & 2.00 & 4.00 & 2.9750 & .53048 \\
\hline $\begin{array}{l}\text { 5: Neutrality and predictive } \\
\text { ability of the annual } \\
\text { reports }\end{array}$ & 40 & $\mathrm{~F} 3, \mathrm{R} 2, \mathrm{R} 1$ & .60 & 3.00 & 4.67 & 3.7083 & .45409 \\
\hline $\begin{array}{l}\text { 6: Fair presentation and } \\
\text { comparability of non- } \\
\text { financial information }\end{array}$ & 40 & $\mathrm{~F} 4, \mathrm{U} 3, \mathrm{C} 3$ & .5 & 2.00 & 3.67 & 3.2250 & .44904 \\
\hline
\end{tabular}

Source: Authors' calculations 
With regard to the first factor (T1, R3, C4, F2 and R5), the mean response (3.0950) implies that the scope and degree of integration of annual reports is average. While reports are published promptly ( $\mathrm{Tl}$ mean score of 3.10 ), more can be done to add to the usefulness of non-financial disclosures and the extent to which they are integrated with the financial performance and objectives of the organisation (Solomon, 2010; 10D, 2009). As at 2010, the extent to which social, health and environmental issues (R3) were disclosed was seen as only marginally useful (mean of 3.43). In addition to integration concerns, there was a lack of inter-organisational comparability, as implied by the C4 mean score of 3.18. Although accounting policy choices are fairly well explained (F2 mean score of 3.58), overall, financial statements provided only limited insight into the short- and long-term sustainability of South African listed entities (R5 mean score of 3.4) largely in line with the concerns of King-III (2009), the IRC (2011) and Solomon \& Maroun (2012).

The second factor deals with changes in accounting policy $(\mathrm{Cl} ; \mathrm{C} 2)$. Companies did not change accounting policies frequently ( $\mathrm{Cl}$ mean score of 4.5), suggesting that retrospective adjustments or restatements were only made to correct errors or otherwise provide more useful information to users. While the lack of restatement or retrospective adjustment could imply that companies avoided corrections or changes to accounting policies, even if in the interest of stakeholders, the scores on Rl and R5, together with the fact that audit reports are rarely modified, suggest that this is not the case. This is also consistent with the score of 3.98 on Factor 3 (U1; U2). The financial information in annual reports was perceived as well structured (U1 mean score of 4.05) and clearly supported by related notes (U2 mean score of 3.9).

The favourable response on Factors 2 and 3 should, however, be contrasted with the mean of 3.48 on C4 and 3.53 on Fl. Despite sound use of accounting policies, structured layout and supporting notes for financial information, overall, comparability of the information contained in the annual reports remains limited. Furthermore, despite the disclosure of some significant assumptions and estimates, more could be done to enhance the clarity of the annual reports, especially when it comes to non-financial information (Solomon and Maroun, 2012). Financial reporting in South Africa appears sound, but the call for more integrated reporting per King III and the IRC is a valid one (Factor 4). As at the end of 2010, there is a disconnect between financial and non-financial information, which limits the relevance of the latter (F5 mean score of 2.43) and identifies a clear area for improvement in corporate reporting models. In particular, sound integrated reporting would enable users to assess the generating of sustainable returns in the short to long run (IRC, 2011). The current state of corporate reporting hinders this (Factor 5). Forward-looking information (such as budgets, forecast and management commentary) plays an important role in complementing the annual reports ( $R 1$ means score of 3.85 ) but preparers have virtually excluded non-financial metrics from these parts of the annual reports (R2 mean score of 3.48). Therefore, the causal nexus between financial performance, governance issues and organisational strategy is not clear (R2 and R4 mean of 3.48 and 3.62 respectively).

Adding to this is the perceived lack of neutrality. Supplementary information provides some clarity (U3 mean score of 3.95), but annual reports were generally perceived as overemphasising transactions, events and conditions that reflected positively on the organisation (Fl mean score of 3.53). When it comes to the comparability and fair presentation of nonfinancial information (Factor 6), in particular, relatively low means of Rl, Fl, F5, C3 and C4 confirm how limited comparability and insufficient integration with financial measures are perceived as threats to the fair presentation and neutrality of the disclosure in annual reports (F4 mean score of 2.93). 


\section{CONCLUSION}

Using the qualitative characteristics of the CF and IRC's discussion paper, this research explored the perceived usefulness of annual reports prepared by listed South African companies with financial years ending on or before 31 December 2010. The intention was not to 'quantify' a measure of reporting quality or utility in a clinical experimental fashion. Instead, using a structured questionnaire, the article highlights the perceptions of a select number of experts on the state of corporate reporting in South Africa at the time of transitioning to integrated reporting.

These experts were of the opinion that, overall, annual reports are decision-useful. For example, changes in accounting policies; restatement of results; the use of notes to the financial statements; and supplementary information were favourably regarded. Other 'elements' of the reports require considerable improvement. In line with King III (2009), the IRC (2011) and the IIRC (2011), the link between financial and non-financial performance needs to be better explained. While non-financial information, such as social, health and environmental issues, is being included in annual reports, the information is lacking in terms of its comparability and level of integration with financial and strategic metrics. More needs to be done to ensure that there is a clear link between the economic activity of the firm, its key risks, business strategy and non-financial performance indicators.

Whether, or to what extent, this will be achieved is a topic for future research. To this end, this article provides a useful 'base case'. Considering how the perceived usefulness of corporate reporting changes over time will provide interesting evidence of the extent to which the integrated reporting model has succeeded in addressing deficiencies in finance-centric annual reports.

This research is not, however, without its limitations. The research instrument - as noted in Section 3 - is subjectively derived. The results also summarise the opinions of a relatively small group of stakeholders. Additional research on the views of a broader group of stakeholders, such as general investors, regulators, environmentalists and non-governmental organisations, for instance, could prove insightful. In addition, by virtue of using a more quantitative approach, the research lacks the exploratory power of more interpretive, qualitative methods. Exploring perceptions of annual reports using detailed interviews, for example, could offer further insights into why and how annual reports fail to meet the information needs of different users and how this can be practically resolved. Following from this, future research exploring the way in which organisations are improving their annual reporting over time; how they have achieved a better integration of financial and non-financial information; and the extent to which the information needs of different stakeholders are being met could prove highly insightful areas for future research.

\section{LIST OF REFERENCES}

Abadir, K.M. (2005). The mean-median-mode inequality: counterexamples. Econometric Theory, 21, pp. 477-482.

Akhigbe, A., Kudla, R.J. \& Madura, J. (2005). Why are some corporate earnings restatements so damaging? Applied Financial Economics, 15(5), pp. 327-336. 
Azam, S.M., Warraich, K.M. \& Awan, S.H. (2011). One report: bringing change in corporate reporting through integration of financial and non-financial performance disclosure, International Journal of Accounting and Financial Reporting, 1(1), pp. 50-70.

Baker C.R. \& Hayes R. (2004). Reflecting form over substance: the case of Enron Corp, Critical Perspective in Accounting, 15, pp. 767-785.

Barth, M.E., Beaver, W.H. \& Landsman, W.R. (2001). The relevance of value relevance literature for financial accounting standard setting: another view, Journal of Accounting and Economics, 31, pp. 77-104.

Barth, M. દ. (2008). Global Financial Reporting: Implications for US Academics. The Accounting Review, 83, pp. 1159-1179.

Barth, M.E., Landsman, W.R. \& Lang, M. (2008). International accounting standards and accounting quality. Journal of Accounting Research, 46(3), pp. 467-498.

Bartov, E. \& Mohanram, P. (2004). Private information, earnings manipulations, and executive stockoption exercises. The Accounting Review, 79(4), pp. 889-1010.

Bartov, E., Goldberg, S. \& Kim, M. (2005). Comparative value relevance among German, US and international accounting standards: a German stock market perspective. Journal of Accounting, Auditing and Finance, 20(2), pp. 95-119.

Bonaci, C.G., Mustata, V.M. \& Mutiu, A. (2011). Determinants of accounting students' academic performance: a factor analysis based approach. Review of Business Research, 11(1), pp. 134-140.

Botten, N. (2009). Management Accounting Business Strategy. Oxford: CIMA Publishing.

Callaghan, C. (2012). The effect of financial capital on inner-city street trading. Journal of Economic and Financial Sciences, 5(1), pp. 83-102.

Cohen, J., Krishnamoorthy, G. \& Wright, A.M. (2002). Corporate governance and the audit process. Contemporary Accounting Research, 19(4), pp. 573-594.

Comrey, A.L. (1978). Common methodological problems in factor analytic studies. Journal of Consulting and Clinical Psychology, 46, pp. 648-659.

Costello, A.M. \& Wittenberg-Moerman, R. (2011). The impact of financial reporting quality on debt contracting: evidence from internal control weakness reports. Journal of Accounting Research, 4(1), pp. $97-136$.

Creswell, J.W. (2009). Research design: qualitative, quantitative and mixed methods approaches, $3^{\text {d }}$ edition. London: Sage Publications.

Deloitte (2012). Integrated reporting: navigating your way to a truly integrated report, $2^{\text {nd }}$ edition. [Online] Available: http://www.deloitte.com/assets/Dcom-

SouthAfrica/Local\%20Assets/Documents/Integrated\%20Reporting\%20Publication $\% 2011 \% 20 \% 28$ elec tronic2\%29.pdf. (Accessed 25 March 2012).

Ford, J.K., MacCallum, R. \& Tait, M. (1986). The application of exploratory factor analysis in applied psychology: a critical review and analysis. Personnel Psychology, 39, pp. 291-314.

Graham, J.R., Harvey, C.R. \& Rajgopal, S. (2005). The economic implication of corporate financial reporting. Journal of Accounting and Economics, 40, pp. 3-73.

Graham, J.R., Li, J. \& Qiu, J. (2008). Corporate misreporting and bank loan contracting. Journal of Financial Economics, 89, pp. 44-61. 
Groth, R.E. \& Bergner, J.A. (2006). Preservice elementary teachers' concept and procedural knowledge of mean, median and mode. Mathematical Thinking and Learning, 8(1), pp. 37-63.

Hatcher, L. (1994). A step-by-step approach to using SAS for factor analysis and structured equation modelling. Cary, NC: SAS Press.

Hayek, F. (1960). The Constitution of Liberty. London: Routledge \& Kegan Paul Ltd.

Healy, P.M. \& Wahlen, J.M. (1999). Revue of the earnings management literature and its implications for standard setting. Accounting Horizon, 13(4), pp. 365-383.

Hussey, J.C. \& Hussey, R. (2003). Business research: a practical guide for undergraduate and postgraduate students, $2^{\text {nd }}$ edition. London: Palgrave Macmillan.

Ilias, A. \& Razak, M.Z.A. (2011). End-user computing satisfaction (EUCS) towards computerised accounting system (CAS) in public sector: a validation of instrument. Journal of Internet Banking and Commerce, 16(2), pp. 1-17.

Institute of Directors in Southern Africa (IOD) (1994). The King Report on Corporate Governance (King-I). Johannesburg: Lexis Nexus South Africa.

Institute of Directors in Southern Africa (IOD) (2002). The King Report on Corporate Governance for South Africa - 2002 (King-II). Johannesburg: Lexis Nexus South Africa.

Institute of Directors in Southern Africa (IOD) (2009). The King Code of Governance for South Africa (2009) and King Report on Governance for South Africa (2009) (King-III). Johannesburg: Lexis Nexus South Africa.

Integrated Reporting Committee of South Africa (IRC). (2011). Framework for Integrated Reporting and the Integrated Report, Discussion Paperissued in January 2011.

International Accounting Standard Board (2010). The Conceptual Framework for Financial Reporting, issued in September 2010, In: South African Institute of Chartered Accountants (ed.) SAICA members' handbook. 2010 ed., Vol. 2A. Pietermaritzburg: LexisNexis.

International Accounting Standard Board (2010a). IFRS practice statement for Management Commentary: A framework for presentation, In: South African Institute of Chartered Accountants (ed.) SAICA members' handbook. 2010 ed., Vol. 2A. Pietermaritzburg: LexisNexis.

International Accounting Standard Board (2010b). IAS 8 Accounting Policies, Changes in Accounting Estimates and Errors. In: South African Institute of Chartered Accountants (ed.) SAICA members' handbook. 2010 ed., Vol. 2A. Pietermaritzburg: LexisNexis.

International Accounting Standard Board. (2010c). IAS 1 Presentation of Financial Statements, In: South African Institute of Chartered Accountants (ed.) SAICA Members' Handbook. 2010 ed., Vol. 2 A. Pietermaritzburg: LexisNexis.

International Integrated Reporting Committee (IIRC). (2011). Towards integrated reporting: communicating value in the 21st Century, I/RC. [Online] Available: http://theiirc.org/wpcontent/uploads/2012/06/Discussion-Paper-Summaryl.pdf. (Accessed 5 June 2012).

Jonas, G.J. \& Blanchet, J. (2000). Assessing quality of financial reporting. Accounting Horizons, 14(3), pp. 353-363.

Kakabadse, A. \& Korac-Kakabadse, N. (2002). Corporate governance in South Africa: evaluation of the King II Report. Journal of Change Management, 2, pp. 305-317. 
Leedy, P.D. \& Ormrod, J.E. (2001). Practical research: planning and design. Upper Saddle River, NJ: Merrill/Prentice Hall.

Maines, L.A. \& Wahlen, J.M. (2006). The nature of accounting information reliability: inference from archival and experimental research. Accounting Horizons, 20(4), pp. 399-425.

Malhotra, N.K. (1996). Factor analysis in marketing research: an applied orientation, $2^{\text {nd }}$ edition. Pennsylvania: Prentice Hall.

Maroun, W., Turner, M. \& Sartorius, K. (2011). Does capital gains tax add to or detract from the fairness of the South African Tax System? South African Journal Economic and Management Sciences, 14(4), pp. 436-448.

McDaniel, L., Martin, R.D. \& Maines, L.A. (2002). Evaluating financial reporting quality: the effect of financial expertise vs. financial literacy. The Accounting Review, 77, pp. 139-167 (supplement).

Morales, R. \& Van Tichelen, દ. (2010). Sustainable stock exchanges, real obstacles, real opportunities. [Online] Available:

http://www.responsibleresearch.com/Responsible_Research__Sustainable_Stock_Exchanges_2010 .pdf. (Accessed l December 2011).

Nichols, D.C. \& Wahlen, J.M. (2004). How do earnings numbers relate to stock returns? A review of classic accounting research with updated evidence. Accounting Horizons, 18(4), pp. 263-286.

Nunnally, J. (1962). The analysis of profile data. Psychological Bulletin, 59(4), pp. 311-319.

0’Dwyer, B., Owen, D. \& Unerman, J. (2011). Seeking legitimacy for new assurance forms: The case of assurance on sustainability reporting. Accounting, Organisations and Society, 36, pp. 31-52.

Reed, J. (2003). Investing in South Africa, Financial Times Limited, 6 October, p. 4.

Rossouw, G.J. (2005). Business ethics and corporate governance in Africa. Business \& Society, 94, pp. 94-106.

Rowley, J. (2012). Conducting research interviews. Management Research Review, 35, pp. 260-271.

Rummel, R.J. (1978). Applied factor analysis. Evanston, IL: Northern University Press.

Sijtsma, K. (2009). On the use, the misuse, and the very limited usefulness of Cronbach's alpha. Psychometrika, 47(1), pp. 107-120.

Solomon, J. F. \& Solomon, A. (2006). Private social, ethical and environmental disclosure. Accounting, Auditing \& Accountability Journal, 19, 564-591.

Solomon, J. (2010). Corporate governance and accountability, $3^{d}$ edition. West Susex: John Wiley.

Solomon, J. \& Maroun, W. (2012). The impact of integrated reporting on social, ethical and environmental reporting in South Africa. In: British Accounting and Finance Association: Annual Conference, April 2012 Brighton, United Kingdom, pp. 1-23.

South African Institute of Chartered Accountants (2011). South Africa's world-first Integrated Reporting Discussion Paper attracts global attention. [Online] Available:

https://www.saica.co.za/News/NewsArticlesandPressmediareleases/tabid/695/itemid/3053/langua ge/en-ZA/language/en-ZA/Default.aspx. (Accessed 5 June 2012).

Tracy, L. (1983). For want of trust a joint venture founders: a lesson in misuse of factor analysis. Proceedings of the $26^{\text {th }}$ Annual Conference of the Midwest Academy of Management, pp. 346-353. 
Van Beest, F., Braam, G. \& Boelens, S. (2009). Quality of financial reporting: measuring qualitative characteristics. Working Paper, Nijmegen Centre of Economics, Institute for Management Research, Radboud University, Nijmegen.

Vaughn, M. \& Ryan, L.V. (2006). Corporate governance in South Africa: a bellwether for the continent? Corporate Governance, 14(5), pp. 504-512.

Watts, R.L. \& Zimmerman, J.L. (1983). Agency Problems, Auditing, and the Theory of the Firm: Some Evidence. Journal of Law and Economics, 26, pp. 613-633. 
APPENDIXA

\section{FIGURE 1: Scree plot:}

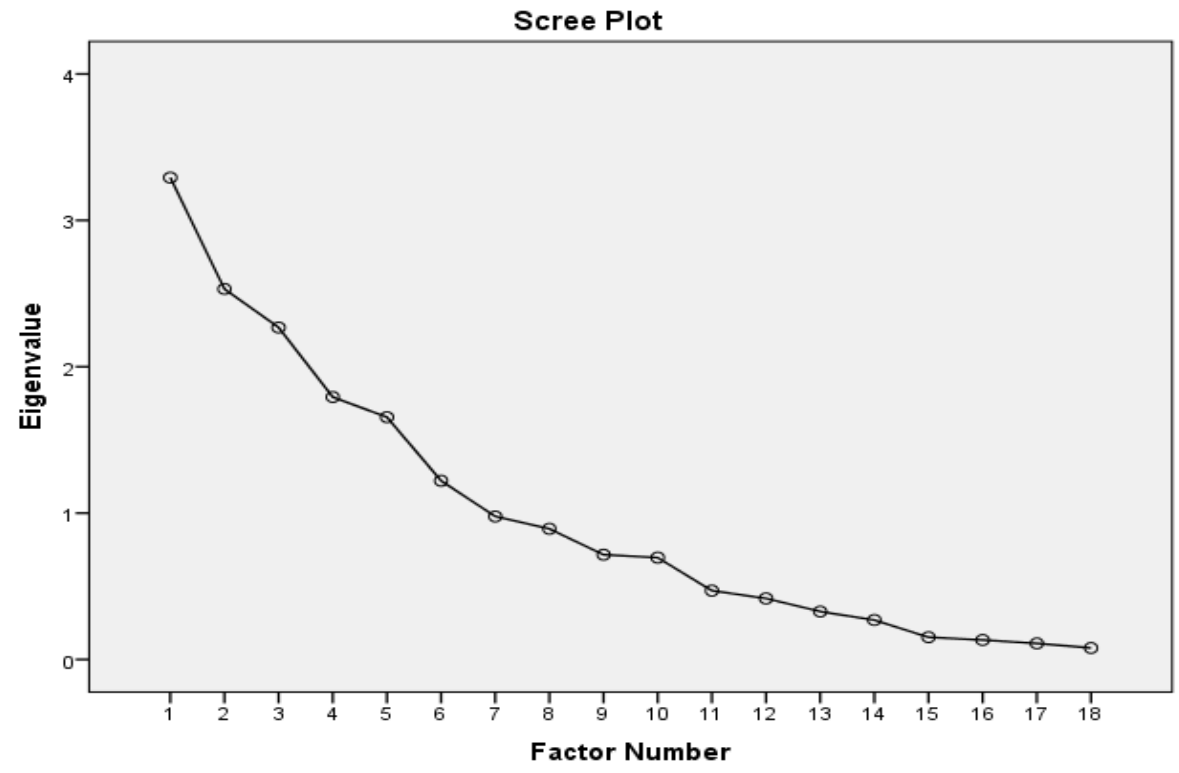




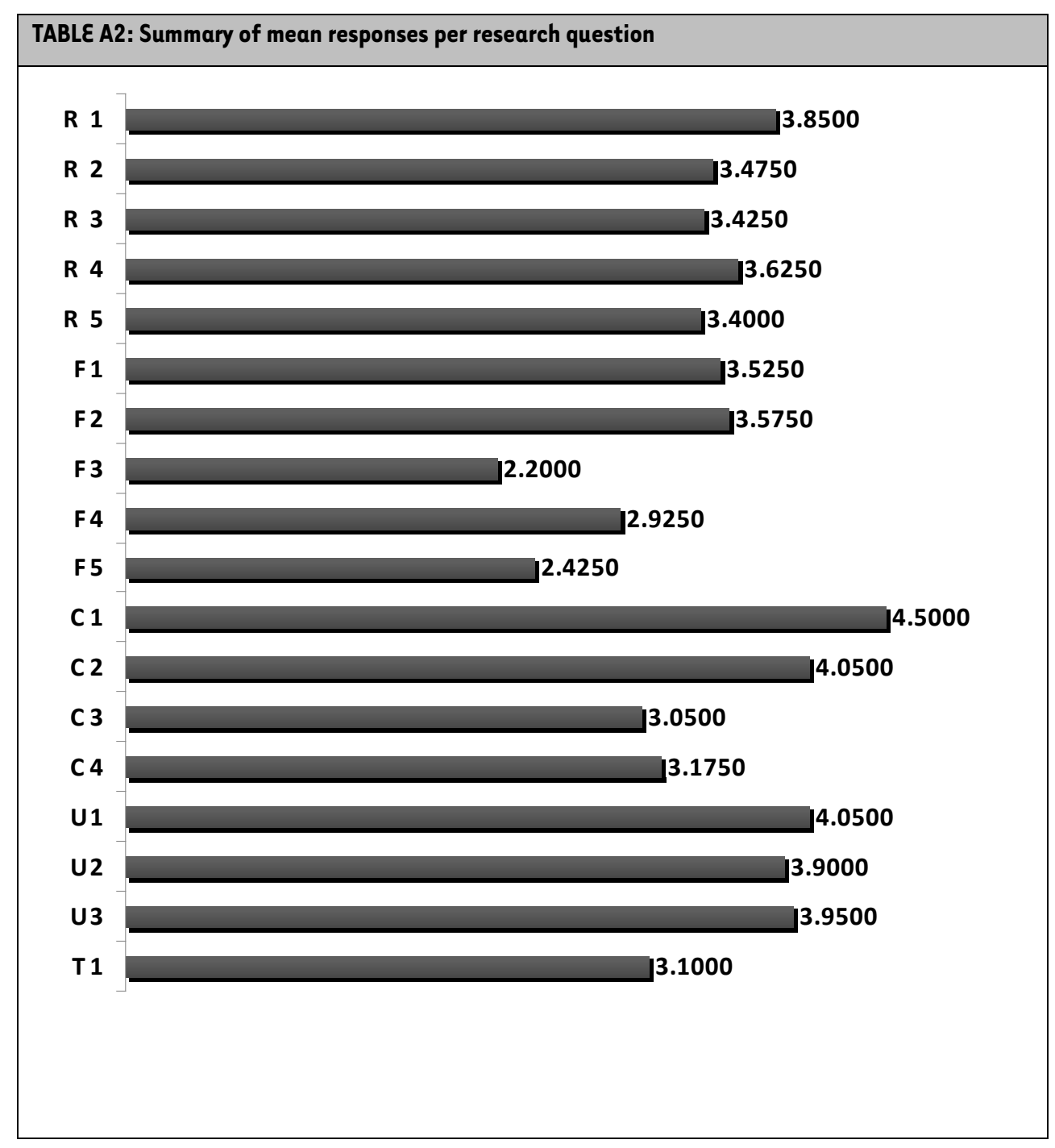

